\title{
Systematic Review - Nutrition in the Elderly
}

\section{Alba Nino, J Gerardo Villa and Pilar S Collado*}

Institute of Biomedicine (IBIOMED), University of Leon, Spain

*Corresponding Author: Pilar S Collado, Institute of Biomedicine (IBIOMED),

University of Leon, Spain.
Received: September 23, 2020

Published: October 07, 2020

(C) All rights are reserved by Pilar S Collado., et al.

\section{Abstract}

Objectives: This systematic review aims to compile the concept of aging, which entails it and the nutritional recommendations that have been addressed in recent years as a preventive measure for the best functional management and better quality of life of these people.

Data Sources: Systematic searches were conducted in the PubMed, Medline and SPORTDiscus databases and manual searches were made in the reference lists of the selected articles.

Study Selection: The selected cohort studies were those that examined the concept and effects of the aging process, as well as the effects of physical activity and especially nutrition in this older population.

Data Extraction: Data was extracted independently.

Data Synthesis: Thirty articles were included in which the subject of aging, physical activity and/or nutrition was discussed.

Conclusion: Older adults are an extremely heterogeneous group, as a result, the assessment of nutritional risk requires careful and centralized individualization, considering physiological changes and possible disease, as well as psychosocial, economic and environmental factors that influence nutritional status, being the basic objectives of maintaining the functional independence and quality of life of these people.

Keywords: Aging; Nutrients; Quality of Life

\section{Introduction}

Justification

The primary aging process is an inevitable deterioration of cellular structure and biological function, regardless of disease, lifestyle or environmental factors. On the other hand, there is secondary aging that refers to additional structural and functional changes that are harmful to age and caused by diseases and lifestyle factors [5]. In turn, there is a definition for healthy aging made by the World Health Organization (WHO), this being the process of development and maintenance of functional capacity that allows well-being in older age, with a functional capacity composed of, the intrinsic capacity of an individual (a compound of all physical and mental capacities), its relevant environmental characteristics and the interactions between them.

This aging process is plastic, and numerous research shows that it can be driven by the accumulation of molecular damage, causing changes in cellular and tissue function that characterize its phenotype. In addition, it is due to a decrease in the positive regulation of various signalling and gene regulation pathways necessary for metabolic and functional adaptations. This cellular, tissue and organ damage can result in the development of fragility, disabilities and age-related diseases [22]. 
The aging process is affected by sexual parameters, with women suffering most from this functional deterioration of autonomy, as after the menopausal transition, sexual steroid concentrations, both estrogen and androgens, decrease drastically. These changes contribute to the worsening of functional independence, disability and an increased risk of hospitalization and mortality. Men instead have a much slower decrease in sex steroids, but from the eighth decade of life, testosterone concentrations begin to decline disminuir rapidly, contributing to decreased lean body mass and increased diseases such as sarcopenia (degenerative loss of muscle mass and strength due to aging factors or by leading a sedentary life).

The daily quality of life of older adults is also affected by disturbances in sleep-wake cycle rhythms. Factors that predispose, cause, and consolidate sleep disorders could include those related to nutrition that is inappropriate to the type of person. In the Goluch-Koniuszy and cols study [13] on older women with sleep disorders, it is observed that women's dietary intake habits in all age groups were unbalanced in terms of calories and nutritional value, which can affect the synthesis of neurotransmitters that regulate the sleep and wakefulness cycle along with melatonin homeostasis. In addition, it has been shown that there is a correlation between sleep disorders with an increased risk of collapse, deterioration of physical and mental condition (slow reaction time, tendency to make more mistakes and deterioration of attention and logical thinking), impaired cognitive functions (memory, decision-making and problem solving), as well as increased mortality.

Regular physical activity is the only intervention that has consistently been shown to improve functional health and energy balance and reduce the risk of cardiovascular disease, stroke, diabetes, various types of cancer, depression and falls. In the elderly, physical activity is also effective in mitigating aging diseases, restoring robustness and preventing and delaying the development of disability [21]. This evidence has led the WHO to recommend participating in regular physical activities at all stages of life.

Decreased fat-free mass and appendicular skeletal muscle mass accelerates in men and women from the age of 60 . Studies like Kyle's [19]; Frontera [12]; Newman [26] and von Haehling [41] highlight data on muscle mass and muscle function, where both begin to decrease at the same time, but muscle function decreases faster than muscle mass, indicating that function may be more sensitive to aging. Therefore, increased levels of physical activity should have protective effects to slow down the progressive loss of muscle function. There is significant variability between individuals in these loss rates. Although some of these differences can be explained by fixed factors, such as sex, much of the remaining variation is inexplicable, which has led to an increase in interest in the influence of adult lifestyle.

The role of diet in the elderly takes on great importance by influencing basic quality of life parameters. As age increases and energy needs decrease, we find a significant decrease in food and energy intake, representing an average drop of about $25 \%$ between the ages of 40 and 70 . The negative consequences of these changes may be aggravated by the effects of functional impairments that older people may experience at a certain point in their lives, see the ability to access and prepare food, the psychological problems they may suffer such as depression and dementia when living in solitude and the social effects of living in a situation where no one usually oversees their particular way of feeding.

Due to the influence of these external nutrition and physical activity parameters, a WHO report on aging and health, published in 2015, recognizes growing evidence of the importance of health-related behaviors. There are several studies that have examined the separate effects of increased physical exercise or dietary supplements on muscle mass and physical performance in older adults, but less is known about the extent to which training benefits could be improved when we combine these interventions. The Bales review [1] shows that the benefits obtained from a weight reduction diet or exercise regimen are very similar to improve fitness, although neither modality claims to be as effective as the two combined. Both external causes of improvement should be seen as united in improving the quality of life of older people.

\section{Study objetives}

In view of the background described, the objectives we set out with this review are as follows:

- $\quad$ Define the aging process.

- $\quad$ Relate the aging process to physical activity and nutrition.

- $\quad$ Collect according to the bibliography a summary of the nutritional requirements for this larger population group.

- $\quad$ Establish a number of nutritional recommendations to increase the quality of life of older people.

\section{Methods}


This bibliographic review was conducted in accordance with the reporting elements chosen for systematic review and metaanalysis guidelines (PRISMA).

\section{Search strategies}

PubMed, Medline and SPORT Discus were used without language restrictions or date of publication, with a systematic search for eligible studies published until 2019. The keywords were ("aging" OR "senior citizens") AND ("nutrition" OR "food" OR "protein intake" OR "water intake" OR "diet") AND ("exercise" OR "training" OR "physical activity" OR "supplementation").

\section{Selection of studies}

Studies were included if they met the following criteria: (1) Meta analysis or clinical trial designs, (2) written in English and/ or articles that were in English translated into Spanish, (3) participants were elderly, (4) interventions consisted of exercise, a diet program, or a combination of both, (5) result measures included one of the following parameters: body composition, metabolic or inflammatory biomarkers, muscle function or physical performance, muscle mass with increased proteins, physical activity intervention program and/or Mediterranean nutrition and diet.

\section{Data collection process}

The data was extracted independently in a Microsoft Excel worksheet; any disagreement was resolved at a consensus meeting. Table 1 presents the summary of the extracted data where the following information was presented: (1) authors, title, year of publication and country, (2) study design, (3) characteristics of the study population (sample size and demographics), (4) types of intervention, (5) duration of intervention and (6) results for body composition, metabolic health, muscle function and physical function.

\section{Results}

\begin{tabular}{|c|c|c|c|c|c|}
\hline $\begin{array}{l}\text { Author, title, year, } \\
\text { country }\end{array}$ & Design & $\begin{array}{l}\text { Features } \\
\text { of the popu- } \\
\text { lation }\end{array}$ & Types of intervention & $\begin{array}{l}\text { Duration of } \\
\text { intervention }\end{array}$ & $\begin{array}{l}\text { Results for body composition, } \\
\text { metabolic health, metabolic } \\
\text { function and physical function }\end{array}$ \\
\hline $\begin{array}{l}\text { Ballesteros JM., et al. } \\
\text { Mediterranean diet } \\
\text { and risk of falling in } \\
\text { community-dwell- } \\
\text { ing older adults. } \\
\text { 2019. Spain. }\end{array}$ & $\begin{array}{l}\text { Prospec- } \\
\text { tive } \\
\text { cohort } \\
\text { study. }\end{array}$ & $\begin{array}{l}2,071 \text { partici- } \\
\text { pants aged } 60 \\
\text { years. }\end{array}$ & $\begin{array}{l}\text { Compliance of the Mediter- } \\
\text { ranean diet with the MEDAS } \\
\text { score was evaluated, and study } \\
\text { participants were monitored } \\
\text { until } 2012 \text { to assess the po- } \\
\text { tential risk of des-adherence } \\
\text { to the diet during the previous } \\
\text { year. }\end{array}$ & 3,5 years & $\begin{array}{l}\text { The Mediterranean diet was } \\
\text { associated with a lower risk } \\
\text { of falling among older Spanish } \\
\text { adults. These findings suggest } \\
\text { that the total benefit of the } \\
\text { Mediterranean diet is due to the } \\
\text { cumulative or synergistic impact } \\
\text { of various foods rather than one. }\end{array}$ \\
\hline $\begin{array}{c}\text { Beasley JM, Wert- } \\
\text { heim BC, Lacroix } \\
\text { AZ, Prentice R, } \\
\text { Neuhouser ML., } \\
\text { et al. Biomarker- } \\
\text { calibrated protein } \\
\text { intake and physi- } \\
\text { cal function in the } \\
\text { Women's Health } \\
\text { Initiative. } 2013 . \\
\text { USA. }\end{array}$ & $\begin{array}{l}\text { Prospec- } \\
\text { tive } \\
\text { cohort } \\
\text { study. }\end{array}$ & $\begin{array}{l}\text { Women } \\
\text { from } 50 \text { to } \\
79 \text { years old } \\
\text { ( } \mathrm{n}=134,961 \text { ) } \\
\text { with dietary } \\
\text { data and one } \\
\text { or more phys- } \\
\text { ical function } \\
\text { measures. }\end{array}$ & $\begin{array}{l}\text { Physical function was assessed } \\
\text { using form RAND-36 abbre- } \\
\text { viated at the beginning and } \\
\text { annually from } 2005 \text { for all WHI } \\
\text { (Women's Health Initiative) } \\
\text { participants and at the closure } \\
\text { of CT participants (Clinical } \\
\text { Trials)) (average } 7 \text { years after } \\
\text { initiation). }\end{array}$ & 5 years & $\begin{array}{l}\text { Higher protein intake measured } \\
\text { in the study is associated with } \\
\text { better physical and performance } \\
\text { function in addition to having } \\
\text { lower rates of decline in post- } \\
\text { menopausal women. }\end{array}$ \\
\hline $\begin{array}{l}\text { Burd NA, Yang Y, } \\
\text { Moore DR, Tang } \\
\text { JE, Tarnopolsky., et } \\
\text { al. Greater stimula- } \\
\text { tion of myofibrillar } \\
\text { protein synthesis } \\
\text { with ingestion of } \\
\text { whey protein isolate } \\
\text { v. micellar casein } \\
\text { at rest and after re- } \\
\text { sistance exercise in } \\
\text { elderly men. } 2012 . \\
\text { Canada. }\end{array}$ & $\begin{array}{l}\text { Prospec- } \\
\text { tive } \\
\text { cohort } \\
\text { study. }\end{array}$ & $\begin{array}{l}\text { Men over } 70 \\
\text { years old. }\end{array}$ & $\begin{array}{l}\text { The effect of consuming pure } \\
\text { isolated micellar casein or } \\
\text { pure whey protein isolate was } \\
\text { determined on the rates of } \\
\text { myofibrillar protein synthesis } \\
\text { (MPS) at rest and after resis- } \\
\text { tance exercise in elderly men. } \\
\text { They received an infusion of } \\
\text { phenylalanine L- [ring-13C6] } \\
\text { to measure this MPS. Par- } \\
\text { ticipants performed a unilat- } \\
\text { eral leg resistance exercise } \\
\text { followed by consumption of } \\
\text { isonitrogenic amounts ( } 20 \mathrm{~g} \text { ) } \\
\text { of micellar casein or whey. }\end{array}$ & 1 year & $\begin{array}{l}\text { Ingestion of whey protein is } \\
\text { consistent with higher rates } \\
\text { of MPS than micellar casein, } \\
\text { both at rest and after resistance } \\
\text { exercise in healthy elderly men. } \\
\text { This result is probably related to } \\
\text { higher hyperaminoaceidemia in } \\
\text { the ingestion of whey. }\end{array}$ \\
\hline
\end{tabular}




\begin{tabular}{|c|c|c|c|c|c|}
\hline $\begin{array}{l}\text { De Morais C, } \\
\text { Oliveira B, Afonso C, } \\
\text { Lumbers M, Raats } \\
\text { M, and De Almeida } \\
\text { MDV. Nutritional } \\
\text { risk of European } \\
\text { elderly. 2013. Por- } \\
\text { tugal. }\end{array}$ & $\begin{array}{l}\text { Logistic } \\
\text { regres- } \\
\text { sion. }\end{array}$ & $\begin{array}{l}644 \text { Euro- } \\
\text { pean citizens, } \\
\text { living freely } \\
\text { in the com- } \\
\text { munity, age } \\
65 \text { and older. }\end{array}$ & $\begin{array}{l}\text { The sample was controlled by } \\
\text { quota for age groups (65-74, } \\
\geq 75 \text { years), gender (male/ } \\
\text { female) and life circumstances } \\
\text { (living alone/with others). A } \\
\text { logistic regression was per- } \\
\text { formed to identify the factors } \\
\text { associated with nutritional } \\
\text { risk. }\end{array}$ & 1 year & $\begin{array}{c}\text { The lowest nutritional risk was } \\
\text { found for BMI of around } 18.5 \mathrm{~kg} \\
\text { / m2. Country of residence, sex, } \\
\text { and age were not found to have } \\
\text { a significant effect on nutritional } \\
\text { risk. }\end{array}$ \\
\hline $\begin{array}{c}\text { Evans W. J. Protein } \\
\text { nutrition, exercise } \\
\text { and aging. } 2013 . \\
\text { USA. }\end{array}$ & $\begin{array}{l}\text { Prospec- } \\
\text { tive } \\
\text { cohort } \\
\text { study. }\end{array}$ & $\begin{array}{c}\text { Over } 65 \text { years } \\
\text { old. }\end{array}$ & $\begin{array}{l}\text { Physical function was assessed } \\
\text { using the RAND-36 form using } \\
\text { strength conditioning. }\end{array}$ & 2 years & $\begin{array}{l}\text { Increasing the protein intake in } \\
\text { the diet (up to } 1.6 \text { g. Kg- } 1 \text { body } \\
\text { weight (BW).day) can improve } \\
\text { hypertrophic response to re- } \\
\text { sistance exercise. In very older } \\
\text { men and women, the use of a } \\
\text { protein and calorie supplement } \\
\text { was associated with greater } \\
\text { strength and muscle mass gains } \\
\text { than using placebo. }\end{array}$ \\
\hline $\begin{array}{l}\text { Friedrich M, and } \\
\text { Goluch-Koniuszy Z. } \\
\text { The effectiveness of } \\
\text { nutritional educa- } \\
\text { tion among women } \\
\text { aged } 60-85 \text { on the } \\
\text { basis of anthropo- } \\
\text { metric parameters } \\
\text { and lipid profiles. } \\
\text { 2017. Poland. }\end{array}$ & $\begin{array}{l}\text { Prospec- } \\
\text { tive } \\
\text { cohort } \\
\text { study. }\end{array}$ & $\begin{array}{l}37 \text { women } \\
\text { between the } \\
\text { age of } 60 \text { and } \\
85 \text { years. }\end{array}$ & $\begin{array}{l}\text { Nutritional status assessment } \\
\text { for body mass index (BMI), } \\
\text { waist circumference(WC)) and } \\
\text { waist height ratio (WHtR) and } \\
\text { nutrition education program } \\
\text { parameters. }\end{array}$ & 4 months & $\begin{array}{l}\text { Applied nutritional education } \\
\text { led to changes in the energy and } \\
\text { nutritional value of women's } \\
\text { diets, specifically improved their } \\
\text { anthropometric parameters and } \\
\text { the resulting values of BMI, WC } \\
\text { and WHtR fact was also reflect- } \\
\text { ed in a substantial decrease in } \\
\text { glucose level and a substantial } \\
\text { increase in the level of HDL-C in } \\
\text { women's blood. }\end{array}$ \\
\hline $\begin{array}{l}\text { Frontera WR, } \\
\text { Hughes VA, Field- } \\
\text { ing RA, Fiatarone } \\
\text { MA, Evans WJ, and } \\
\text { Roubenoff R. Aging } \\
\text { of skeletal muscle: } \\
\text { a 12-yr longitudinal } \\
\text { study. 2000. USA. }\end{array}$ & $\begin{array}{l}\text { Prospec- } \\
\text { tive } \\
\text { cohort } \\
\text { study. }\end{array}$ & $\begin{array}{l}12 \text { healthy } \\
\text { sedentary } \\
\text { men. }\end{array}$ & $\begin{array}{l}12 \text { healthy sedentary men } \\
\text { were studied in 1985-86 (T1) } \\
\text { and } 9 \text { of them (initial average } \\
\text { age } 65.4+/-4.2 \text { years) were } \\
\text { reassessed in 1997-98 (T2), } \\
\text { using computed tomography. }\end{array}$ & 12 years & $\begin{array}{l}\text { Quantitative loss in muscle } \\
\text { CSA (cross-sectional area) } \\
\text { of the thigh is an important } \\
\text { contributor to decreased } \\
\text { muscle strength observed with } \\
\text { advanced age and, along with } \\
\text { muscle strength in T1, repre- } \\
\text { sents } 90 \% \text { of the variability in } \\
\text { strength in T2. }\end{array}$ \\
\hline $\begin{array}{l}\text { Goluch-Koniuszy } \\
\text { Z, Fugiel J, and } \\
\text { Salmanowicz M. A } \\
\text { survey of dietary } \\
\text { intake habits and } \\
\text { nutritional status in } \\
\text { women aged 60-90 } \\
\text { years suffering from } \\
\text { sleep disorders. } \\
\text { 2017. Russia. }\end{array}$ & $\begin{array}{l}\text { Question- } \\
\text { naire } \\
\text { survey on } \\
\text { nutri- } \\
\text { tional } \\
\text { status and } \\
\text { habits in } \\
\text { women. }\end{array}$ & $\begin{array}{l}141 \text { women } \\
\text { from } 60-90 \\
\text { years old. }\end{array}$ & $\begin{array}{l}\text { Anthropometric measure- } \\
\text { ments of (body mass and } \\
\text { height) and body mass index } \\
\text { (BMI) were made. Calories / } \\
\text { Energy and Nutritional Values } \\
\text { from Assessed Daily Dietary } \\
\text { Intakes at } 330 \text { meals using } \\
\text { PDCAAS (Aminoprotein Acid } \\
\text { Corrected Digestibility Score) } \\
\text { calculation. }\end{array}$ & 2 months & $\begin{array}{l}\text { Women's eating habits in all age } \\
\text { groups were not balanced in } \\
\text { terms of calories and nutritional } \\
\text { value, which may affect the syn- } \\
\text { thesis of neurotransmitters that } \\
\text { regulate the sleep and wakeful- } \\
\text { ness cycle along with melatonin } \\
\text { homeostasis. }\end{array}$ \\
\hline $\begin{array}{c}\text { Hill E, Hodge A, } \\
\text { Clifton P, Shivappa } \\
\text { N, Hebert JR., et } \\
\text { al. Longitudinal } \\
\text { nutritional changes } \\
\text { in aging Australian } \\
\text { women. } 2019 . \text { Aus- } \\
\text { tralia. }\end{array}$ & $\begin{array}{l}\text { Prospec- } \\
\text { tive } \\
\text { cohort } \\
\text { study. }\end{array}$ & $\begin{array}{c}173 \text { women } \\
\text { with an aver- } \\
\text { age age of } 55 \\
\text { years. }\end{array}$ & $\begin{array}{l}\text { Diet was evaluated using the } \\
\text { Dietary Questionnaire for } \\
\text { Epidemiological Studies ver- } \\
\text { sion } 2 \text { in } 1998 \text { and } 2012 . \text { In } \\
\text { addition, the measurement of } \\
\text { nutritional intakes, Dietary In- } \\
\text { flammation Index (DII) scores, } \\
\text { and Mediterranean diet scores } \\
\text { were used in the WHAP proj- } \\
\text { ect (Project on Aging Healthy } \\
\text { Women). }\end{array}$ & 14 years & $\begin{array}{l}\text { The energy consumption de- } \\
\text { creases significantly over time. } \\
\text { Adherence to the Mediterranean } \\
\text { diet decreases over time and } \\
\text { scores (IIC) increase slightly, } \\
\text { although the latter result is not } \\
\text { significant. }\end{array}$ \\
\hline
\end{tabular}




\begin{tabular}{|c|c|c|c|c|c|}
\hline $\begin{array}{l}\text { Hung Y, Wijnhoven } \\
\text { AH, Visser M, and } \\
\text { Verbeke W. Ap- } \\
\text { petite and Protein } \\
\text { Intake Strata of } \\
\text { Older Adults in the } \\
\text { European Union: } \\
\text { Socio-Demographic } \\
\text { and Health Charac- } \\
\text { teristics, Diet-Re- } \\
\text { lated and Physical } \\
\text { Activity Behaviours. } \\
\text { 2019. Belgium. }\end{array}$ & Survey. & $\begin{array}{l}\text { Older adults } \\
\text { (65 years or } \\
\text { older) ( } \mathrm{n}= \\
\text { 1825) in five } \\
\text { EU countries } \\
\text { (Netherlands, } \\
\text { United King- } \\
\text { dom, Finland, } \\
\text { Spain and } \\
\text { Poland). }\end{array}$ & $\begin{array}{l}\text { Survey using the } 14 \text {-item } \\
\text { Pro55 + analyzer and two } \\
\text { multivariate linear regression } \\
\text { models to identify behav- } \\
\text { ioral determinants that could } \\
\text { explain the likelihood of lower } \\
\text { protein intake stratified by ap- } \\
\text { petite status. }\end{array}$ & 1 year & $\begin{array}{l}\text { Recommendations for optimal } \\
\text { diet and physical activity strate- } \\
\text { gies to prevent protein mal- } \\
\text { nutrition should be discussed } \\
\text { and adapted according to the } \\
\text { profiles of older adults. }\end{array}$ \\
\hline $\begin{array}{l}\text { Jennings A, Berend- } \\
\text { sen AM, de Groot } \\
\text { L, Feskens EJ, } \\
\text { Brzozowska A., et } \\
\text { al. Mediterranean- } \\
\text { Style Diet Improves } \\
\text { Systolic Blood Pres- } \\
\text { sure and Arterial } \\
\text { Stiffness in Older } \\
\text { Adults: Results of } \\
\text { a 1-Year European } \\
\text { Multi-Center Trial. } \\
\text { 2019. Holland. }\end{array}$ & $\begin{array}{l}\text { Cross- } \\
\text { sectional } \\
\text { study } \\
\text { within } \\
\text { the Dutch } \\
\text { National } \\
\text { Food Con- } \\
\text { sumption } \\
\text { Survey. }\end{array}$ & $\begin{array}{c}\text { Mens and } \\
\text { women from } \\
70 \text { to } 94 \\
\text { years old. }\end{array}$ & $\begin{array}{l}\text { Assess the effect of a Mediter- } \\
\text { ranean diet style on Systolic } \\
\text { Blood Pressure and Arterial } \\
\text { Stiffness scores by scoring } \\
\text { (E-NRF) for an elderly group } \\
\text { compared to the NU-AGE (New } \\
\text { Dietary Strategies Index that } \\
\text { address the specific needs } \\
\text { of the elderly population for } \\
\text { healthy aging in Europe). }\end{array}$ & 3 years & $\begin{array}{l}\text { The E-NRF score is a useful } \\
\text { tool for assessing the nutri- } \\
\text { ent density of diets within the } \\
\text { elderly population. No index has } \\
\text { previously been developed with } \\
\text { the aim of assessing the nutrient } \\
\text { density of diets and foods that } \\
\text { specifically indicates dietary ref- } \\
\text { erence values for older adults. }\end{array}$ \\
\hline $\begin{array}{l}\text { Kretser AJ, Voss T, } \\
\text { Kerr WW, Cavadini } \\
\text { C, and Friedmann J. } \\
\text { Effects of two mod- } \\
\text { els of nutritional } \\
\text { intervention on } \\
\text { homebound older } \\
\text { adults at nutritional } \\
\text { risk. 2003. USA. }\end{array}$ & $\begin{array}{l}\text { Prospec- } \\
\text { tive com- } \\
\text { parative } \\
\text { study. }\end{array}$ & $\begin{array}{c}203 \text { older } \\
\text { adults (age } \\
60 \text { to } 90 \\
\text { years). }\end{array}$ & $\begin{array}{l}\text { To test the feasibility of two } \\
\text { home delivery models with } \\
\text { MOW applicants (home } \\
\text { meals) who were identified as } \\
\text { malnourished or "at risk" as } \\
\text { determined by the validated } \\
\text { Mini Nutritional Assessment } \\
\text { (MNA). }\end{array}$ & 6 months & $\begin{array}{l}\text { Home food applicants have } \\
\text { different nutritional needs. By } \\
\text { addressing nutritional risk, } \\
\text { interventions can be focused to } \\
\text { meet these needs. A new com- } \\
\text { prehensive and restorative meal } \\
\text { program improved nutritional } \\
\text { status and reduced nutritional } \\
\text { risk, possibly affecting indepen- } \\
\text { dence and functionality. }\end{array}$ \\
\hline $\begin{array}{l}\text { Manz F, Johner SA, } \\
\text { Wentz A, Boeing H, } \\
\text { and Remer T. Water } \\
\text { balance through- } \\
\text { out the adult life } \\
\text { span in a German } \\
\text { population. } 2012 . \\
\text { Germany. }\end{array}$ & $\begin{array}{l}\text { Prospec- } \\
\text { tive } \\
\text { cohort } \\
\text { review. }\end{array}$ & $\begin{array}{c}1528 \text { German } \\
\text { adults (18-88 } \\
\text { years). }\end{array}$ & $\begin{array}{l}\text { Urine samples collected over a } \\
\text { 24-hour period were analyzed } \\
\text { to calculate water intake } \\
\text { (drinks, food and metabolic } \\
\text { water) and water excretion pa- } \\
\text { rameters for non-renal water } \\
\text { losses (NRWL), urine volume, } \\
\text { recommended urine volume } \\
\text { and to estimate hydration } \\
\text { status (free water reserve) and } \\
\text { adequate intake (AI). }\end{array}$ & 2 months & $\begin{array}{l}\text { Total water requirements do } \\
\text { not change with age, although } \\
\text { aging affects various parameters } \\
\text { of water metabolism. Reducing } \\
\text { sweat loss with increasing age } \\
\text { seems to be primarily respon- } \\
\text { sible for this observation. }\end{array}$ \\
\hline
\end{tabular}




\begin{tabular}{|c|c|c|c|c|c|}
\hline $\begin{array}{l}\text { Newman AB, MPH, } \\
\text { Kupelian V, Visser } \\
\text { M, Simonsick E., et } \\
\text { al. Sarcopenia: alter- } \\
\text { native definitions } \\
\text { and associations } \\
\text { with lower extrem- } \\
\text { ity function. 2003. } \\
\text { USA. }\end{array}$ & $\begin{array}{c}\text { Obser- } \\
\text { vational } \\
\text { cohort } \\
\text { study. }\end{array}$ & $\begin{array}{l}\text { Participants } \\
\text { were be- } \\
\text { tween } 70 \text { and } \\
79 \text { years old. }\end{array}$ & $\begin{array}{c}\text { Participants absorciometry } \\
\text { evaluated using dual-energy } \\
\text { X-ray absorptiometry and clas- } \\
\text { sified as sarcopenic using two } \\
\text { different approaches to adjust } \\
\text { lean mass for body size: lean } \\
\text { appendicular mass divided } \\
\text { by squared height (aLM /ht }{ }^{2)} \text { ) } \\
\text { and lean appendicular mass } \\
\text { adjusted for height and body } \\
\text { fat (waste). }\end{array}$ & 1 year & $\begin{array}{l}\text { Findings suggest that fat mass } \\
\text { should be considered when } \\
\text { estimating the prevalence of sar- } \\
\text { copenia in women and people } \\
\text { who are overweight or obese. }\end{array}$ \\
\hline $\begin{array}{l}\text { Riobó P, Sierra R, } \\
\text { Soldo J, Gómez-Can- } \\
\text { dela C, García PP, } \\
\text { and Serra-Majem } \\
\text { L. Special consider- } \\
\text { ations for nutrition- } \\
\text { al studies in elderly. } \\
\text { 2015. Spain. }\end{array}$ & $\begin{array}{l}\text { Prospec- } \\
\text { tive } \\
\text { cohort } \\
\text { study. }\end{array}$ & Older people. & $\begin{array}{l}\text { Measurement of protein intake } \\
\text { biomarkers. }\end{array}$ & & $\begin{array}{l}\text { In the elderly, the Body Shape } \\
\text { Index appears to be a reliable } \\
\text { measure of adiposity and is as- } \\
\text { sociated with mortality. Further } \\
\text { studies are needed to clarify } \\
\text { the best method for reliably } \\
\text { estimating food and drink intake } \\
\text { in the elderly population and for } \\
\text { assessing nutritional status. }\end{array}$ \\
\hline $\begin{array}{l}\text { Tanaka T, Tale- } \\
\text { gawkar S, Jin Y, } \\
\text { Colpo M, Ferrucci } \\
\text { L and Bandinelli } \\
\text { S. Adherence to } \\
\text { a Mediterranean } \\
\text { Diet Protects from } \\
\text { Cognitive Decline in } \\
\text { the Invecchiare in } \\
\text { Chianti Study of Ag- } \\
\text { ing. 2018. China. }\end{array}$ & $\begin{array}{l}\text { Epidemi- } \\
\text { ological } \\
\text { research. }\end{array}$ & $\begin{array}{l}11,709 \text { peo- } \\
\text { ple between } \\
\text { the age of } 21 \\
\text { and } 102 .\end{array}$ & $\begin{array}{l}\text { Initial differences in demo- } \\
\text { graphic and clinical variables } \\
\text { were tested using variance } \\
\text { analysis for continuous } \\
\text { variables and chi-square for } \\
\text { categorical variables. To exam- } \\
\text { ine the association between } \\
\text { MDS (Mediterranean diet } \\
\text { score) and longitudinal change } \\
\text { in cognitive function, the risk } \\
\text { of cognitive impairment was } \\
\text { assessed as the time to the } \\
\text { first follow-up visit, where } \\
\text { MMSE (Mini Metal State Exam) } \\
\text { decreased by } 5 \text { or more units. }\end{array}$ & 19 years & $\begin{array}{l}\text { The study supports that dietary } \\
\text { recommendations towards a } \\
\text { Mediterranean diet could be } \\
\text { critical to decreasing rates of } \\
\text { cognitive decline. }\end{array}$ \\
\hline
\end{tabular}

\section{Study selection}

According to search keywords, 11333 original studies were initially identified from databases. After the repeated information was deleted, the titles and summaries of 250 studies were examined. After selection, the full texts of 42 studies were evaluated. Of which another 15 were eliminated as bibliographic revisions leaving their use exclusively to the theoretical framework.

With this; other studies that did not correspond to the objec- tives identified were excluded, even if they referred to nutrition and physical activity, including those marked, involving subjects of other ages, those with a disease or those who analyzed different types of pathologies and diseases.

\section{Elderly and nutritional requirements}

After the bibliographical review carried out, it can be observed that the healthy diet, varied and balanced (valued in quantity, energy value 30 - $35 \mathrm{kcal} / \mathrm{kg}$ body weight (BW)/day and quality, en- 
ergy supply of the main macronutrients: $60 \%$ carbohydrates, $15 \%$ protein and less than $30 \%$ fats), is one that provides the energy necessary to maintain our daily activity and a stable weight, that is, the one that maintains a balance between energy intake and organic consumption or expenditure. A prototype of this diet is the "Mediterranean diet", a traditional diet characterized by a high intake of plant foods (fruits, vegetables, cereals, nuts and legumes), dairy products (mainly yogurt and cheese), the use of olive oil as the main source of monounsaturated fats, moderate consumption of fish, birds and eggs, low consumption of red meats and avoid alcoholic beverages [3-7].

It is important to note that even Recommended Daily Intake Amount (RDA) may not always provide optimal intake for the older population because in general, RDA were determined based on studies in younger, healthier populations. There is therefore a potential need for individually adapted nutrient requirements with the use of medicines or possible diseases.

Older adults often fall below the nutritional intake recommendations in some nutrient groups despite the lower energy needs they present, this is due to possible inefficiencies related to aging in the absorption and use of such nutrients, being necessary for this population even more nutrient-rich foods to meet their changing needs. An example of these changes can be seen in Hill's longitudinal study [15] which analyses nutritional changes in a sample of women from age 55 to 70, where energy-adjusted and absolute carbohydrate intake had decreased over time, while also adherence to the Mediterranean diet. In contrast, intake of total fats, saturated fats, monounsaturated fats and energy-adjusted cholesterol increased over time.

Nutrient groups consumed improperly by a large segment of the larger population also se include protein, fatty acids $n-3$, dietary fiber, carotenoids (vitamin A precursors), calcium, sodium, magnesium, phosphorus, potassium and vitamins B6, B12, D and E [38]. In addition, on the one hand, an inadequate intake is indicated in foods of fruits, vegetables, legumes, whole grains, nuts or seeds, fish, lean meat, chicken and dairy products, low-fat liquids, and on the other hand an intake excess of refined grains, processed and fatty meats, fried foods, solid fats, and added sugars is indicated [32]. All of these nutrients that tend to be over-consumed could lead to a risk of obesity, hypertension and related chronic conditions [38].
Supplements may be needed for these nutritional deficiencies, and when health conditions or medications interfere with the absorption or effective use of specific nutrients, making it difficult or impossible to obtain adequate intakes only from the diet [38].

In particular, taking into account the intake of proteins in the elderly population, its adequate consumption plays a critical role in muscle mass, strength and functionality in general being especially important for the elderly. At the adult population level, a protein intake of $0.8{\mathrm{~g} . ~ \mathrm{Kg}^{-1}}(\mathrm{BW})$ represents the recommended daily amount of protein intake necessary for the preservation of muscle mass and strength. However, an increase in the amount of protein in the range of 1,0 - 1,2 g. $\mathrm{kg}^{-1} \mathrm{BW}$ has been proposed, given the reduced anabolic response to protein intake that appears to occur in older adults [6].

Various research supports the increase in recommended values of protein consumption, as they relate to a lower risk of fragility, loss of lean body mass, slow running speed, dipenia and imbalance. Also studies such as Coelho-Junior [6], Verlaan [40] or Robinson [28] have come to the conclusions that a very high protein intake $(1.2 \mathrm{~g} / \mathrm{kg} \mathrm{BW} /$ day) and high (1.0 g/kg BW/day) is associated with better physical performance of the lower limbs as well as a greater gain in muscle mass, compared to low protein consumption $(<0.80$ $\mathrm{g} / \mathrm{kg} \mathrm{BW/day),} \mathrm{in} \mathrm{older} \mathrm{adults.}$

If we refer specifically to some types of training, the protein effect might not have the same benefits, for example, Thomas' review [36] notes in its results that protein supplementation did not significantly increase the effects of overloaded workouts on any of the specified results. But we should establish specific diet plans based on the individual characteristics of the person along with their type of physical activity, as these results may vary for each type of exercise.

The increased in protein consumptium has also been studied in a group of institutionalized older people, in the Tieland study [37], concluding that achieving adequate protein and energy intake is more likely when proteins are uniformly distributed throughout the day. Providing high-protein foods, especially at breakfast and in the evening, can contribute to protein adequacy and healthy aging, especially for the institutionalized elderly. 
Older people often use several medications at once and may also have alcohol consumption, so they more often have vitamin and nutrient deficiencies. The most commonly mentioned are folic acid, iron, vitamins C, B1, B6, B12, D and E, zinc, among others. For those with these deficiencies, in addition to a varied diet it would be useful in certain cases to use a vitamin supplement [32].

It may also be advisable to increase the consumption of some minerals, as presented by the van Dronkelaar study [39] in its thorough analysis of them, in terms of muscle metabolism, calcium, potassium and sodium play a major role for healthy muscle and nerve activity. Magnesium in turn has a positive effect on muscle relaxation being able to improve its function, since it is involved in the synthesis of proteins and ATP, zinc is able to delay oxidative processes, which are known to contribute to disuse and muscle atrophy, iron contributes to maintaining physical requirement, phosphorus protects against muscle weakness and selenium avoids the possible association that can have a deficiency of this with various muscle diseases. This group of minerals appear to be promising to prevent and/or further treat aging-related diseases such as sarcopenia [32].

In Shlisky's research [32], addressing the particular case of postmenopausal women, it is noted that current data, but not uniformly, provide evidence on the beneficial effect of vitamin D supplementation on muscle strength, physical performance and prevention of falls and fractures in elderly women's populations. But the results show that it is still unclear whether and to what extent treatment modalities, such as dose, mode of administration and duration of supplementation, could influence the outcome of treatment, therefore studies with higher methodological characteristics are needed to establish a role for vitamin D in the treatment of some diseases such as sarcopenia in postmenopausal women.

Continuing nutrient supplementation, several trials have been disappointing, emphasizing that all foods are important. Exceptions include vitamin B12, supplements from which they can correct deficiency associated with atrophic gastritis and use of acid blocking drugs, metformin and vitamin $\mathrm{D}$ for people who receive inadequate sun exposure and during the winter months at the northern latitudes. Higher amounts of vitamin E may also be needed to maintain an optimal immune response and increase resistance to respiratory infections [32].

Aging affects several parameters of water metabolism, according to some authors, the mean total water intake decreases with increased age, urine volume increases due to decreased renal concentration capacity and sweat loss would be reduced [23]. Within the concept of a geriatric patient, alterations in water and mineral metabolism are the cause of circulatory collapse, stroke and increased instability, falls and delirium. The body can, in the wide range of balance within the internal environment, compensate for variations, however, always only for a limited period of time, and this compensatory capacity is seen to decrease particularly in advanced age. Maintaining water and mineral balance in the elderly is also complicated by polymorbidity. The frequent occurrence of cardiovascular diseases and the decline in renal functions that may appear throughout life, result in reduced compensatory capacities, the state of which must be rigorously considered [42].

More research is needed to clarify methods that could be better and simpler when accurately estimating fluid intake in food and beverages in the eldest population, and to assess nutritional and hydration status. Furthermore, it is necessary to take into account the importance of carrying out a routine examination of the nutritional status and early diagnosis of malnutrition in older adults, both in the community and in the hospital environment, as this is usually not prioritized; for example, in the European Health, Aging and Retirement Survey, a third of adults over the age of 80 reported that they had not been weighed by their general doctor; in addition, older adults commonly report that they do not receive advice on the diet of their doctor or other health professionals, this situation being even worse in middle- and low-income countries [28]. In the same line of need for educational nutrition program, Friedrich's study [11] shows the importance of an educational program, since four-month nutritional education in older in women resulted in wrong eating habits in addition to an improvement in their nutrition.

\section{Conclusion}

Older adults are an extremely heterogeneous group, and nutritional problems, although prevalent, rarely have a unique cause. As a result, nutritional risk assessment requires careful and centralized individualization, considering the physiological changes related to aging and possible disease, as well as the psychosocial, economic and environmental factors that influence nutritional status, with the basic objectives being to maintain the functional independence and quality of life of these people.

Despite the high prevalence of malnutrition in the elderly, health professionals do not yet recognize nutritional problems as a priority. Recent studies have shown that consumers need addition- 
al ways to choose foods to deliver the right calories and maintain their weight while consuming the right essential nutrients. They also need more information about the variation of nutrients within food groups and the nutrient content of these foods. Each person should be able to evaluate their diet and set realistic individual dietary goals; which involves learning how to buy and prepare food with the possibility of expanding your repertoire of diets achieving a diet appropriate to your circumstances.

\section{Bibliography}

1. Bales CW and Porter Starr KN. "Obesity Interventions for Older Adults: Diet as a Determinant of Physical Function". Advances in Nutrition 9.2 (2018): 151-159.

2. Ballesteros, J. M., et al. Mediterranean diet and risk of falling in community-dwelling older adults. Clinical nutrition, 39.1(2020): 276-281.

3. Beasley JM., et al. "Biomarker-calibrated protein intake and physical function in the Women's Health Initiative". Journal of the American Geriatrics Society 61.11 (2013): 1863-1871.

4. Burd NA., et al. "Greater stimulation of myofibrillar protein synthesis with ingestion of whey protein isolate v. micellar casein at rest and after resistance exercise in elderly men". British Journal of Nutrition 108.6 (2012): 958-962.

5. Cartee GD., et al. "Exercise promotes healthy aging of skeletal muscle". Cell Metabolism 23.6 (2016): 1034-1047.

6. Coelho-Júnior H., et al. "Relative Protein Intake and Physical Function in Older Adults: A Systematic Review and Meta-Analysis of Observational Studies". Nutrients 10.9 (2018): 1330.

7. De Morais C., et al. "Nutritional risk of European elderly". European Journal of Clinical Nutrition 67.11 (2013): 1215-1219.

8. Edwards MH., et al. "Osteoporosis and sarcopenia in older age". Bone 80 (2015): 126-130.

9. Evans WJ. "Protein nutrition, exercise and aging". Journal of Advances in Computer Networks 23.6 (2004): 601S-609S.

10. Franzke B., et al. "Dietary Protein, Muscle and Physical Function in the Very Old". Nutrients 10.7 (2018): 935.

11. Friedrich M and Goluch-Koniuszy Z. "The effectiveness of nutritional education among women aged $60-85$ on the basis of anthropometric parameters and lipid profiles". Roczniki Państwowego Zakładu Higieny 68.3 (2017): 253-260.

12. Frontera WR., et al. "Aging of skeletal muscle: a 12-yr longitudinal study". Journal of Applied Physiology 88.4 (2000): 13211326.
13. Goluch-Koniuszy Z., et al. "A survey of dietary intake habits and nutritional status in women aged 60-90 years suffering from sleep disorders". Roczniki Państwowego Zakładu Higieny 68.4 (2017): 355-364.

14. Guigoz Y. "The Mini Nutritional Assessment (MNA®) review of the literature-what does it tell us?" Journal of Nutrition Health Aging 10.6 (2006): 466-485.

15. Hill E., et al. "Longitudinal nutritional changes in aging Australian women". Asia Pacific Journal of Clinical Nutrition 28.1 (2019): 139-149.

16. Hung Y., et al. "Appetite and Protein Intake Strata of Older Adults in the European Union: Socio-Demographic and Health Characteristics, Diet-Related and Physical Activity Behaviours". Nutrients 11.4 (2019): 777.

17. Jennings A., et al. "Mediterranean-Style Diet Improves Systolic Blood Pressure and Arterial Stiffness in Older Adults: Results of a 1-Year European Multi-Center Trial". Hypertension 73.3 (2019): 578-586.

18. Kretser AJ., et al. "Effects of two models of nutritional intervention on homebound older adults at nutritional risk". Journal of the Academy of Nutrition and Dietetics home 103.3 (2003): 329-336.

19. Kyle UG., et al. "Age-related differences in fat-free mass, skeletal muscle, body cell mass and fat mass between 18 and 94 years". European Journal of Clinical Nutrition 55.8 (2001): 663667.

20. Liao Y., et al. "Prospective Views for Whey Protein and/or Resistance Training Against Age-related Sarcopenia". Aging and Disese 10.1 (2019): 157-174.

21. Marzetti E., et al. "Physical activity and exercise as countermeasures to physical frailty and sarcopenia". European Educational Research Journal 29.1 (2017): 35-42.

22. Mathers JC. "Nutrition and ageing: knowledge, gaps and research priorities". Proceedings of the Nutrition Society 72.2 (2013): 246-250.

23. Manz F., et al. "Water balance throughout the adult life span in a German population". British Journal of Nutrition 107.11 (2012): 1673-1681.

24. Mobarhan S and Trumbore LS. "Nutritional problems of the elderly". Concept of Genetics in Nursing 7.2 (1991): 191-214.

25. Nascimento CM., et al. "Sarcopenia, frailty and their prevention by exercise". Free Radical Biology and Medicine 132 (2018): 4249. 
26. Newman AB., et al. "Sarcopenia: alternative definitions and associations with lower extremity function". Journal of the American Geriatrics Society 51.11 (2003): 1602-1609.

27. Riobó P., et al. "Special considerations for nutritional studies in elderly”. Nutrición Hospitalaria 31.3 (2015): 84-90.

28. Robinson SM., et al. "Does nutrition play a role in the prevention and management of sarcopenia?" Clinical Nutrition 37.4 (2017): 1121-1132.

29. Roubenoff R. "Sarcopenia and its implications for the elderly". European Journal of Clinical Nutrition 54 (2000): S40-S47.

30. Schlanger LE., et al. "Electrolytes in the aging". Advances in Chronic Kidney Disease 17.4 (2010): 308-319.

31. Shafiee G., et al. "Prevalence of sarcopenia in the world: a systematic review and meta-analysis of general population studies". Journal of Diabetes and Metabolic Disorders 6.1 (2017): 21.

32. Shlisk J., et al. "Nutritional considerations for healthy aging and reduction in age-related chronic disease". Advances in Nutrition 8.1 (2017): 17-26.

33. Sorenson AW and Ford M. "Diet and health for senior citizens: workshops by the health team". The Gerontologist 21.3 (1981): 257-262.

34. Tanaka T., et al. "Adherence to a Mediterranean Diet Protects from Cognitive Decline in the Invecchiare in Chianti Study of Aging”. Nutrients 10.12 (2018): 2007.

35. Tannou T., et al. "Multifactorial immunodeficiency in frail elderly patients: Contributing factors and management". Médecine et Maladies Infectieuses 4.3 (2019): 167-172.

36. Thomas DK., et al. "Protein supplementation does not significantly augment the effects of resistance exercise training in older adults: a systematic review". Journal of the American Medical Directors Association 17.10 (2016): 959-e1.

37. Tieland M., et al. "An Even Distribution of Protein Intake Daily Promotes Protein Adequacy but Does Not Influence Nutritional Status in Institutionalized Elderly". Journal of the American Medical Directors Association 19.1 (2018): 33-39.

38. Tucker KL. "High-Risk Nutrients in the Aging Population". En: Watkins C, Locher JL and Saltzman E. Handbook of Clinical Nutrition and Aging. 3 ed. New York: Humana Press (2015): 335-353.
39. van Dronkelaar C., et al. "Minerals and sarcopenia; the role of calcium, iron, magnesium, phosphorus, potassium, selenium, sodium, and zinc on muscle mass, muscle strength, and physical performance in older adults: a systematic review". Journal of the American Medical Directors Association 19.1 (2017): 6-11.

40. Verlaan S., et al. "Sufficient levels of 25-hydroxyvitamin D and protein intake required to increase muscle mass in sarcopenic older adults-The PROVIDE study". Clinical Nutrition 37.2 (2017): 551-557.

41. von Haehling S and Anker SD. "Cachexia as a major underestimated and unmet medical need: facts and numbers". Journal of Cachexia Sarcopenia Muscle 1.1 (2010): 1-5.

42. Zadák Z., et al. "Electrolyte and water disorders in old age". Vnitrni lekarstvi 64.11 (2018): 1059-1066.

\section{Assets from publication with us}

- Prompt Acknowledgement after receiving the article

- Thorough Double blinded peer review

- Rapid Publication

- Issue of Publication Certificate

- High visibility of your Published work

Website: www.actascientific.com/

Submit Article: www.actascientific.com/submission.php Email us: editor@actascientific.com

Contact us: +919182824667 